\title{
USPOSTAVLJANJE I ZAŠTITA EKOLOŠKE MREŽE NATURA 2000 U EUROPSKOJ UNIJI I HRVATSKOJ
}

\author{
UDK: $502 / 504: 34(4)$ \\ Izvorni znanstveni rad \\ Primljeno: 10. 12. 2015.
}

\begin{abstract}
U radu se pojašnjavaju odredbe propisa Europske unije koji se odnose na zaštitu prirode, a kojima je uspostavljena ekološka mreža Natura 2000 (Direktiva 2009/147/EZ o očuvanju divljih ptica te Direktiva 92/43/EEZ o očuvanju prirodnih staništa i divlje faune i flore). U tu svrhu prikazuju se presude Suda Europske unije u vezi s tumačenjem odredaba navedenih direktiva. Cilj tog prikaza jest dobiti odgovor na pitanje kako se uspostavlja ekološka mreža Natura 2000 u državama članicama te koju razinu zaštite prirode moraju pružiti države članice prilikom odobravanja izvođenja zahvata koji bi mogli imati nepovoljan utjecaj na zaštićena područja. U radu se zatim analizira proces uspostavljanja ekološke mreže Natura 2000 u Hrvatskoj. Budući da je postupak uspostavljanja ekološke mreže dug proces koji traje godinama, posebna pozornost posvećuje se pitanju trenutka od kojeg su države članice dužne zaštititi područja koja će tek postati područja od interesa za Europsku uniju kad ih usvoji Europska komisija. U radu se također ukazuje na problem neusklađenosti pojedinih prijevoda osnovnih pojmova iz propisa Europske unije na hrvatski jezik. S tim u vezi pojašnjavaju se određene razlike u terminologiji koje postoji u trenutno važećim hrvatskim propisima, ali i prema predloženim izmjenama.
\end{abstract}

\section{Ključne riječi: zaštita prirode, ekološka mreža Natura 2000, Direktiva o očuvanju prirodnih staništa i divlje faune i flore, Direktiva o očuvanju divljih ptica}

\section{UVOD ${ }^{1}$}

O zakonskoj zaštiti područja osobitih prirodnih vrijednosti počelo se raspravljati krajem 19. stoljeća, a ključnim događajem u povijesti zaštite prirode smatra se proglašenje prvoga nacionalnog parka u svijetu (Yellowstone, SAD) 1872. godine. ${ }^{2}$ Prve pojave ideja zaštite prirode u Hrvatskoj također se javljaju krajem 19. stoljeća. ${ }^{3}$ Takve inicijative davale su razne udruge građana za zaštitu i očuvanje prirodnih vrijednosti, koje su se počele osnivati krajem 19. i početkom 20. sustav".

1 Rad je nastao u okviru projekta Pravnog fakulteta Sveučilišta u Zagrebu „Novi hrvatski pravni

2 Medvedović, D., „Zaštita nekih dijelova okoliša u hrvatskom pravnom sustavu“, u: LončarićHorvat, O. (ur.), Pravo okoliša, Organizator, Zagreb, 2003., str. 99.

3 V. detaljno o povijesnom razvoju zaštite prirode u Hrvatskoj: Medvedović, D., „Razvoj upravnopravne zaštite okoliša u Hrvatskoj“, str. 3-85, u: Barbić, J. (ur.). Upravnopravna zaštita okoliša Gdje smo bili, a gdje smo sada?, Hrvatska akademija znanosti i umjetnosti, Zagreb, 2015., poseban otisak. 
stoljeća po uzoru na slične udruge u Europi. ${ }^{4} \mathrm{U}$ to doba se započelo i s uvođenjem pojedinih odredaba o zaštiti prirode u zakonodavne akte. Primjerice, 1893. godine donesen je Zakon o zaštiti ptica, a Zakonom o lovu (također iz 1893.) ptice pjevice bile su potpuno zaštićene, a šumska se divljač u njemu štitila određivanjem kruga osoba koje smiju loviti, ograničenjem mjesta dopuštenog lova (lovišta) te zabranama i ograničenjem sredstava i načina lova. ${ }^{5}$ Početkom 20. stoljeća Plitvička jezera namjeravala su se proglasiti nacionalnim parkom, u vrijeme kada su se proglašavali i prvi nacionalni parkovi u Europi, no do trajnog proglašenja došlo je tek 1949. godine (NN br. 29/49). ${ }^{6}$ Djelovanje u cilju zaštite Plitvičkih jezera zapravo je započelo još 1899., kada je ban Kraljevine Hrvatske i Slavonije donio naredbu kojom se ,ustanovljuje građevni red za okolicu plitvičkih jezera između sela Leskovca i Plitvica“. 7 U tom je građevnom redu iscrpno propisano kakve se kuće, gospodarske zgrade i putovi smiju graditi u tom području, kako se moraju uređivati okućnice, određuje se obveza sadnje drvoreda i gradnje pločnika, a također se vodila briga o zaštiti jezera od mogućeg onečišćenja te se zabranjivalo izbacivanje izmetina i ocjedina u jezero. ${ }^{8} \mathrm{U}$ tablici 1 . prikazan je slijed zakonske regulacije zaštite prirode u Hrvatskoj od donošenja prvog zakona u tom području nakon Drugog svjetskog rata do danas.

Tablica 1.: Zakonsko uređenje zaštite prirode u Hrvatskoj - kronološki prikaz ${ }^{9}$

\begin{tabular}{|c|c|}
\hline 1945. & $\begin{array}{l}\text { Zakon o zaštiti spomenika kulture i prirodnih rijetkosti Demokratske } \\
\text { Federativne Jugoslavije, Službeni list DFJ, br. } 54 / 45 \text {. }\end{array}$ \\
\hline 1946. & $\begin{array}{l}\text { Opći zakon o zaštiti spomenika kulture i prirodnih rijetkosti, }{ }^{*} \text { Službeni list } \\
\text { FNRJ, br. } 81 / 46 \text { i } 4 / 51 \text {. }\end{array}$ \\
\hline 1949. & Zakon o zaštiti spomenika kulture i prirodnih rijetkosti, NN br. 84/49. \\
\hline 1960. & Zakon o zaštiti prirode, NN br. 19/60. \\
\hline 1965. & Zakon o zaštiti prirode, NN br. 34/65. \\
\hline 1976. & $\begin{array}{l}\text { Zakon o zašiti prirode, } \mathrm{NN} \text { br. } 54 / 76 \text {. Zakon je izmijenjen i dopunjen četiri } \\
\text { puta: NN br. } 25 / 77,41 / 83,31 / 86 \text { i } 47 / 86 \text {. }\end{array}$ \\
\hline 1994. & $\begin{array}{l}\text { Zakon o zašiti prirode, NN br. 30/94. Zakon je izmijenjen i dopunjen dva puta: } \\
\text { NN br. } 72 / 94 \text { i } 107 / 03 \text {. }\end{array}$ \\
\hline 2003. & Zakon o zašiti prirode, NN br. 162/03. \\
\hline 2005. & $\begin{array}{l}\text { Zakon o zašiti prirode, NN br. 70/05. Zakon je izmijenjen i dopunjen dva puta: } \\
\text { NN br. } 139 / 08 \text { i } 57 / 11 \text {. }\end{array}$ \\
\hline 2013. & Zakon o zaštiti prirode, NN br. 80/13. \\
\hline \multicolumn{2}{|c|}{$\begin{array}{l}\text { * Zakon o zaštiti spomenika kulture i prirodnih rijetkosti iz 1945. je nakon donošenja Ustava FNRJ } \\
\text { djelomice izmijenjen 1946. godine, kao i njegov naziv, tako da je njegov pročišćeni tekst glasio: Opći } \\
\text { zakon o zaštiti spomenika kulture i prirodnih rijetkosti. (cit. prema: ibid., str. 34.) }\end{array}$} \\
\hline \multicolumn{2}{|c|}{4 Ibid., str. 16.} \\
\hline \multicolumn{2}{|c|}{5 Ibid., str. 17.} \\
\hline \multicolumn{2}{|r|}{ lovic, D., „Lastita ne } \\
\hline \\
\hline \multicolumn{2}{|c|}{8 Ibid. } \\
\hline 9 & \\
\hline
\end{tabular}


U okviru procesa pristupanja Europskoj uniji, strateški cilj politike zaštite prirode u Hrvatskoj bio je zadovoljiti sve nužne preduvjete za ispunjenje obveza predviđenih propisima Europske unije. Potencijalnom kandidatkinjom za članstvo Hrvatska je postala u listopadu 2001. godine, potpisivanjem Sporazuma o stabilizaciji i pridruživanju (NN-MU br. 132/01), a u veljači 2003. podnijela je službeni zahtjev za članstvom. Otada su aktivnosti razvoja sustava zaštite prirode najviše povezane s pripremama Republike Hrvatske za pristupanje Europskoj uniji, osobito nakon zaprimanja pozitivnog službenog mišljenja (avisa) Europske komisije o hrvatskoj kandidaturi u travnju 2004. godine. ${ }^{10}$

Pravni temelj za zaštitu prirode u Europskoj uniji predstavljaju dvije direktive - Direktiva 79/409/EEZ o očuvanju divljih ptica ${ }^{11}$ (danas vrijedi kodificirana verzija - Direktiva 2009/147/EZ o očuvanju divljih ptica) ${ }^{12}$ te Direktiva 92/43/ EEZ o očuvanju prirodnih staništa $\mathrm{i}$ divlje faune i flore, ${ }^{13}$ zadnje izmijenjena $\mathrm{i}$ dopunjena Direktivom Vijeća 2013/17/EU o prilagodbi određenih direktiva u području okoliša zbog pristupanja Republike Hrvatske. ${ }^{14}$ Provedbom tih dviju Direktiva (skraćeno se nazivaju Direktiva o pticama i Direktiva o staništima) uspostavljena je ekološka mreža Natura 2000 kojoj je cilj osigurati dugoročni opstanak najvrednijih i najugroženiji vrsta i staništa. Mreža se sastoji od dviju skupina područja - posebnih područja očuvanja koja su države članice obvezne odrediti temeljem Direktive o staništima te područja posebne zaštite koja se uspostavljaju temeljem Direktive o pticama.

Pravo Europske unije u području zaštite prirode razvija se putem tumačenja direktiva od strane Suda Europske unije (dalje i: Sud EU) ${ }^{15}$ u prethodnim postupcima, kao i njegovih presuda povodom tužbi Europske komisije protiv država članica zbog neispunjavanja obveza utemeljenima na pravu EU. Stoga je prvi cilj ovog rada pojasniti pojedine odredbe Direktive o pticama (poglavlje 2.) i Direktive o staništima (poglavlje 3.) kako ih je protumačio Sud EU u svojim presudama. Zaključci koji će proizaći iz tog prikaza ukazivat će na to da je Sud EU zauzeo strogi pristup u odnosu na iznimke kojima bi se državama članicama dopustilo da odobre izvođenje zahvata u zaštićenim područjima. ${ }^{16}$ Takvi zaključci bitni su za javnopravna tijela koja provode postupke odobravanja projekata koji bi mogli imati značajan utjecaj na područje Nature 2000, kao i za upravne sudove

10 Za detaljnije informacije v. Pregled stanja biološke i krajobrazne raznolikosti te stanja sustava zaštite prirode u Republici Hrvatskoj u: Strategija i akcijski plan zaštite biološke i krajobrazne raznolikosti Republike Hrvatske, NN br. 143/08.

11 OJ L 103, 25. 4. 1979., str. 1-18.

12 OJ L 20, 26.1. 2010., str. 7-25.

13 OJ L 206, 22. 7. 1992., str. 7-50. Posebno izdanje na hrvatskom jeziku: poglavlje 15, svezak 2, str. 14-57.

14 OJ L 158, 10. 6. 2013., str. 193-229. Posebno izdanje na hrvatskom jeziku: poglavlje 15, svezak 27, str. 143-179.

15 Zbog jednostavnosti u radu, koristit će se naziv Sud EU i u onim predmetima koji su se vodili pred njime u vrijeme kad mu je naziv bio Sud Europskih zajednica. 1135

16 Kingston, S., Environment, u: International \& Comparative Law Quarterly, 2010., 59(4), str. 
koji su nadležni odlučivati o tužbama protiv odluka (rješenja) kojima se ti projekti odobravaju. Pored toga, poznavanje značenja odredaba direktiva od velike je koristi i za javnost, što uključuje i stručnu javnost, zainteresiranu za pitanja zaštite okoliša i prirode. Naime, sukladno Konvenciji o pristupu informacijama, sudjelovanju javnosti u odlučivanju i pristupu pravosuđu u pitanjima okoliša ${ }^{17}$ (Aarhuška konvencija), javnost ima pravo sudjelovati u postupcima o odobravanju projekata koji mogu imati značajan utjecaj na okoliš, a zainteresirana javnost ima i pravo pristupa pravosuđu. Drugi cilj ovog rada jest prikazati proces uspostavljanja ekološke mreže Natura 2000 u Hrvatskoj (poglavlje 4.). S obzirom na problem neusklađenosti pojedinih prijevoda osnovnih pojmova na hrvatski jezik, ukazat će se i na određene razlike u terminologiji koja postoji u mjerodavnim propisima (trenutno važećima, ali i prema predloženim izmjenama). U zaključku (poglavlje 5.) sumirat će se glavne spoznaje do kojih se došlo tijekom istraživanja.

\section{DIREKTIVA 79/409/EEZ O OČUVANJU DIVLJIH PTICA ODNOSNO DIREKTIVA 2009/147/EZ O OČUVANJU DIVLJIH PTICA - KODIFICIRANA VERZIJA}

U ovom poglavlju pojasnit će se pojedine odredbe Direktive o očuvanju divljih ptica prema njezinoj kodificiranoj verziji iz 2009. godine koje se odnose na zaštitu njihovih staništa. ${ }^{18}$ Direktiva iz 2009. zamijenila je Direktivu 79/409/EEZ koja je bila najstariji zakonodavni tekst Unije koji se odnosio na zaštitu prirode. Direktiva o pticama uspostavila je prvi put opći sustav za zaštitu svih vrsta divljih ptica koje prirodno obitavaju na teritoriju država članica Unije. U preambuli Direktive izraženo je stajalište da su divlje ptice, koje uključuju velik broj migracijskih vrsta, zajednička baština država članica Europske unije, te da njihovo očuvanje, da bi bilo učinkovito, zahtijeva suradnju na globalnoj razini.

\section{a) Područje koje se uređuje Direktivom}

Direktiva o pticama odnosi se na očuvanje svih vrsta divljih ptica koje prirodno obitavaju na europskom državnom području država članica na koje se primjenjuje Ugovor. Ona se odnosi na zaštitu tih vrsta, upravljanje i nadzor nad tim vrstama i njome se utvrđuju pravila o njihovom iskorištavanju (v. članak 1., stavak 1.). Primjenjuje se na ptice, njihova jaja, gnijezda i staništa (v. članak 1., stavak 2.). Sukladno sudskoj praksi Suda EU, opći sustav zaštite koji Direktiva nastoji uspostaviti odnosi se na sve vrste ptica, čak i ako su takve vrste rijetke. ${ }^{19}$ Odredba nacionalnog zakonodavstva koja ograničava zaštitu na vrste ptica koje žive $u$ divljini u skladu je sa zahtjevima Direktive, ako takva zaštita obuhvaća vrste ptica

17 NN-MU br. $1 / 07$.

18 Odredbe koje se odnose na mjere zaštite ptica (članci 4. - 11.) neće se razmatrati.

19 C-247/85 Commission of the European Communities v Kingdom of Belgium [1987] ECR 3029, par. 52 . 
koje žive prirodno ili uobičajeno na teritoriju država članica. Osim toga, ptice koje samo prolaze kroz države članice moraju se smatrati da žive prirodno u divljini u državi članici, čak i ako je to samo u ograničenom vremenskom razdoblju. ${ }^{20}$

Države članice moraju poduzimati potrebne mjere za održavanje populacije vrsta divljih ptica na razini koja odgovara posebno ekološkim, znanstvenim i kulturološkim zahtjevima, istodobno uzimajući u obzir gospodarske i rekreacijske zahtjeve, ili za prilagođavanje tih vrsta toj razini (v. članak 2.). Prema stajalištu Suda EU, ova odredba Direktive ne može se koristiti kao samostalna osnova za odstupanje od obveza i zahtjeva Direktive. ${ }^{21}$

S obzirom na prethodno spomenute zahtjeve, države članice dužne su poduzimati potrebne mjere za očuvanje, održavanje ili ponovnu uspostavu dovoljne raznolikosti i veličine staništa za sve vrste divljih ptica (v. članak 3., stavak 1.). Očuvanje, održavanje ili ponovna uspostava biotopa i staništa prvenstveno uključuju sljedeće mjere:

(a) stvaranje zaštićenih područja;

(b) održavanje i upravljanje u skladu s ekološkim potrebama staništa unutar i izvan zaštićenih zona;

(c) ponovno uspostavljanje uništenih biotopa; te

(d) stvaranje biotopa (v. članak 3., stavak 2.).

Obveze za države članice koje proizlaze iz članka 3. postoje prije nego što se zamijetilo bilo kakvo smanjenje broja ptica i prije nego što se ostvarila bilo kakva opasnost za zaštićene vrste kojima prijeti izumiranje. ${ }^{22}$

\section{b) Klasificiranje područja posebne zaštite ${ }^{23}$ i osiguravanje njihove pravne zaštite}

Vrste ptica navedene u Prilogu I. Direktive predmet su posebnih mjera očuvanja koje se odnose na njihova staništa, kako bi se osiguralo njihovo preživljavanje i razmnožavanje na njihovu području raširenosti. S tim u vezi, uzimaju se u obzir:

(a) vrste u opasnosti od izumiranja;

(b) vrste osjetljive na određene promjene u njihovim staništima;

(c) vrste koje se smatraju rijetkima zbog male populacije ili ograničene lokalne raširenosti;

(d) druge vrste koje zahtijevaju posebnu pažnju zbog posebne prirode njihovih staništa.

20 Ibid., par. 21.

${ }^{21}$ C-262/85 Commission of the European Communities v Italian Republic [1987] ECR 3073, par. 37.

22 C-355/90 Commission of the European Communities v Kingdom of Spain („Santoña Marshes”) [1993] ECR I-4221, par. 15.; C-117/00 Commission of the European Communities v Ireland („,OwenduffNephin Beg Complex") [2002] ECR I-5335, par. 15.

23 Engl. SPA - special protection areas. 
Trendovi i promjene populacijskih razina uzimaju se u obzir kao podloga za ocjenjivanje. Države članice dužne su posebno klasificirati područja koja su, s obzirom na broj i veličinu, najprimjerenija kao posebna zaštićena područja ${ }^{24} \mathrm{za}$ očuvanje tih vrsta u okviru morskih i kopnenih zemljopisnih područja gdje se primjenjuje ova Direktiva (v. članak 4., stavak 1.).

Države članice su također dužne poduzimati slične mjere za migracijske vrste koje se redovito pojavljuju a nisu navedene u Prilogu I., imajući na umu potrebu za njihovom zaštitom u okviru morskih i kopnenih zemljopisnih područja gdje se ova Direktiva primjenjuje s obzirom na područja za njihovo razmnožavanje, mitarenje i prezimljavanje te odmorišta duž njihovih migracijskih putova. $U$ tu svrhu države članice trebaju obratiti posebnu pozornost na zaštitu močvarnih područja, a posebno na močvarna područja od međunarodnog značaja (v. članak 4., stavak 2.).

Odredbama stavaka 1. i 2. članka 4. zahtijeva se od država članica da pruže posebnim zaštićenim područjima režim pravne zaštite kojim će se osigurati preživljavanje i razmnožavanje vrsta ptica koje su navedene u Prilogu I. te razmnožavanje, mitarenje i prezimljavanje migracijskih vrsta koje nisu navedene u tom Prilogu. ${ }^{25}$ Sukladno članku 4., stavku 1., ako vrsta navedena u Prilogu I. obitava na njihovu teritoriju, države članice moraju klasificirati kao posebna zaštićena područja ona područja koja su s obzirom na broj i veličinu najprikladnija za njihovo očuvanje. Tu obvezu nije moguće izbjeći usvajanjem drugih posebnih mjera očuvanja. ${ }^{26}$

U provedbi Direktive države članice nisu ovlaštene pozvati se, prema svojem izboru, na razloge za odstupanje koji se temelje na uzimanju u obzir drugih interesa. Preciznije, s obzirom na obvezu poduzimanja posebnih mjera očuvanja za određene vrste iz članka 4., takvi razlozi moraju, da bi bili prihvatljivi, odgovarati općem interesu koji bi bio nadređen u odnosu na opći interes predstavljen ekološkim ciljem Direktive. Pritom interesi koji se spominju u članku 2., tj. gospodarski i rekreacijski zahtjevi, ne ulaze u obzir, budući da ta odredba ne predstavlja samostalno odstupanje od općeg sustava zaštite koji je uspostavljen Direktivom. ${ }^{27}$

Ornitološki kriteriji propisani u stavcima 1. i 2. članka 4. oni su kriteriji koji daju smjernice državama članicama za određivanje i definiranje granica posebnih zaštićenih područja. Države članice nisu ovlaštene uzeti u obzir ekonomske

24 Prijevod pojma special protection areas (SPA) koji se koristi u hrvatskoj verziji Direktive o pticama i Direktive o staništima nije isti. U Direktivi o pticama SPA se prevodi kao posebna zaštićena područja, a u Direktivi o staništima kao posebna područja zaštite.

25 C-166/97 Commission of the European Communities v French Republic (,Seine Estuary”) [1999] ECR I-1719 par. 21; C-96/98 Commission of the European Communities v French Republic („Poitevin Marsh") [1999] ECR I-8531, par. 22; C-415/01 Commission of the European Communities v Kingdom of Belgium [2003] ECR I-2081, par. 15.

26 C-3/96 Commission of the European Communities v Kingdom of the Netherlands [1998] ECR I-3031, par. 55.

27 C-355/90 Commission of the European Communities v Kingdom of Spain (,Santoña Marshes”), par. 19 . 
(gospodarske) zahtjeve navedene u članku 2. pri odabiru i određivanju granica posebnih zaštićenih područja niti čak uzeti u obzir ekonomske zahtjeve koji predstavljaju opći interes koji je nadređen onome koji je predstavljen ekološkim ciljem Direktive. ${ }^{28}$

Država članica ne može smanjiti površinu posebnog zaštićenog područja niti izmijeniti njegove granice, osim ako područja koja su isključena iz posebnog zaštićenog područja više nisu najprimjerenija područja za očuvanje vrsta divljih ptica u smislu članka 4., stavka 1. Direktive. ${ }^{29}$

Odredbe Direktive moraju se provoditi s neupitnom obvezujućom snagom te s određenošću, preciznošću i jasnoćom koja je potrebna da bi zadovoljila zahtjeve pravne sigurnosti. Načelo pravne sigurnosti zahtijeva odgovarajući publicitet nacionalnih mjera usvojenih sukladno pravilima Zajednice na takav način da se osobama zainteresiranima za te mjere omogući da utvrde opseg svojih prava i obveza u određenom području na koje se odnosi pravo Zajednice. Što se tiče karata koje označavanju posebna zaštićena područja, one moraju imati neupitnu obvezujuću snagu. ${ }^{30}$

\section{c) Sprečavanje onečišćavanja ili pogoršavanja stanja staništa}

Članak 4., stavak 4. Direktive o pticama glasi: „U vezi sa zaštićenim područjima iz stavaka 1.i 2. [članka 4.], države poduzimaju odgovarajuće mjere za sprečavanje onečišćavanja ili pogoršavanja stanja staništa ili bilo kakvih poremećaja koji negativno utječu na ptice u tolikoj mjeri da bi to bilo značajno s obzirom na ciljeve ovog članka. Države članice također nastoje spriječiti onečišćavanje ili pogoršavanje stanja staništa i izvan tih zaštićenih područja."

Prva rečenica članka 4., stavka 4. zahtijeva od država članica da poduzmu odgovarajuće korake kako bi se spriječilo, između ostalog, pogoršavanje stanja staništa, ne samo u područjima koja su klasificirana kao posebna zaštićena područja u skladu s člankom 4., stavkom 1., već i u područjima koja su najprimjerenija za očuvanje divljih ptica, čak i ako nisu klasificirana kao posebna zaštićena područja, pod uvjetom da zaslužuju takvu klasifikaciju. Iz toga slijedi, s obzirom na potonja područja, da bilo koja povreda prve rečenice članka 4., stavka 4. pretpostavlja da područja u pitanju spadaju među područja koja su s obzirom na broj i veličinu najprimjerenija za očuvanje zaštićenih vrsta u smislu podstavka 4 . članka 4 . stavka 1. , te da su ta područja pretrpjela pogoršanje. ${ }^{31}$

28 C-44/95 Regina v Secretary of State for the Environment, ex parte: Royal Society for the Protection of Birds - „Lappel Bank” [1996] ECR I-3805, par. 26-31.

29 C-191/05 Commission of the European Communities v Portuguese Republic [2006] ECR I-6853, par. 13.

30 C-415/01 Commission of the European Communities v Kingdom of Belgium, par. 21-22.

31 C-96/98 Commission of the European Communities v French Republic („Poitevin Marsh”), par. 41-42. 
U pogledu deklasificiranja posebnih zaštićenih područja, sve dok područje ispunjava uvjete iz članka 4., stavka 1., deklasifikacija (primjerice, putem smanjenja veličine područja), nije moguća, osim u slučaju ako su ispunjeni uvjeti iz članka 6., stavaka 2. do 4. Direktive o staništima (v. infra).

Nakon stupanja na snagu Direktive o staništima, ako se radi o područjima koja su klasificirana ili priznata sukladno članku 4., stavcima 1. ili 2. Direktive o pticama, obveze iz prve rečenice članka 4., stavka 4. zamijenjene su obvezama propisanima u članku 6., stavcima 2. do 4. Direktive o staništima. Dakle, primjenjuju se samo obveze iz članka 6., stavaka 2. do 4. i to od: (a) datuma provedbe Direktive o staništima ili (b) od datuma klasifikacije ili priznanja područja temeljem Direktive o pticama, ako je potonji datum kasniji (v. članak 7. Direktive o staništima).

Ako se radi o područjima koja su najprimjerenija za očuvanje divljih ptica, ali ih država članica nije klasificirala kao posebna zaštićena područja, premda zaslužuju takvu klasifikaciju, takva područja i dalje potpadaju pod režim uređen prvom rečenicom članka 4., stavka 4. Direktive o staništima. ${ }^{32}$

\section{DIREKTIVA 92/43/EEZ O OČUVANJU PRIRODNIH STANIŠTA I DIVLJE FAUNE I FLORE}

Cilj Direktive o staništima jest doprinijeti osiguranju biološke raznolikosti putem očuvanja prirodnih staništa i divljih životinjskih i biljnih vrsta na europskom području država članica (v. članak 1.). Kao i Direktiva o pticama, Direktiva o staništima propisuje mjere za zaštitu područja očuvanja (članci 3. - 11.) te druge mjere za zaštitu vrsta (članci 12. - 16.). ${ }^{33}$ Među mjerama koje su namijenjene zaštiti područja očuvanja, ključne su one koje se odnose na određivanje posebnih područja očuvanja u svrhu osnivanja koherentne europske ekološke mreže tih područja pod nazivom Natura 2000. Ova mreža sastavljena je od područja u kojima se nalaze prirodni stanišni tipovi navedeni u Prilogu I. i staništa vrsta navedenih u Prilogu II. Mreža Natura 2000 obuhvaća i područja posebne zaštite koja države članice klasificiraju u skladu s Direktivom o pticama (v. članak 3., stavak 1.).

\section{a) Pravna zaštita predloženih područja od značaja za Zajednicu, ${ }^{34}$ područja od značaja za Zajednicu ${ }^{35}$ i posebnih područja očuvanja ${ }^{36}$}

Posebna područja očuvanja određuju se prema postupku koji je propisan Direktivom o staništima (v. članke 4. - 5.). Države članice, na temelju kriterija utvrđenih u Prilogu III. (Faza 1) i relevantnih znanstvenih informacija, predlažu

32 C-374/98 Commission of the European Communities v French Republic („Basses Corbières”), par. 47.

33 U ovom radu pojasnit će se samo odredbe koje se odnose na zaštitu staništa.

34 Engl. pSCI - proposed sites of Community importance.

35 Engl. SCI - sites of Community importance.

36 Engl. SAC - special areas of conservation. 
popis područja uz naznaku koji se prirodni stanišni tipovi i vrste prirodno nalaze na tom području (v. članak 4., stavak 1.). U ovoj fazi postupka jedino su dozvoljeni argumenti koji se odnose na očuvanje te nije dozvoljeno neuključivanje nekog područja zbog gospodarskih, socijalnih i kulturnih potreba. ${ }^{37}$ Sukladno Direktivi, razlikuju se prioritetni prirodni stanišni tipovi i prioritetne vrste te oni koji nisu prioritetni.

Temeljem popisa koji predlože države članice, Komisija sastavlja nacrt popisa područja od značaja za Zajednicu u kojima se navode područja na kojima se nalaze jedan ili više prioritetnih prirodnih stanišnih tipova ili prioritetnih vrsta. Države članice čija područja na kojima se nalaze jedan ili više prioritetnih prirodnih stanišnih tipova i prioritetnih vrsta predstavljaju više od $5 \%$ njihova nacionalnog teritorija mogu, u dogovoru s Komisijom, zatražiti slobodniju primjenu kriterija navedenih u Prilogu III. (Faza 2) pri odabiru svih područja od značaja za Zajednicu na svojem području. Popis područja odabranih kao područja od značaja za Zajednicu Komisija usvaja u skladu s postupkom utvrđenim člankom 21. (v. članak 4., stavak 2.).

Ako Komisija utvrdi da nacionalni popis ne spominje područje u kojem se nalazi prioritetan prirodni stanišni tip ili prioritetna vrsta koje Komisija na temelju relevantnih i pouzdanih znanstvenih informacija smatra bitnim za održavanje ili opstanak, pokreće se postupak bilateralnih savjetovanja između te države članice i Komisije s ciljem usporedbe znanstvenih podataka koje svaka od njih koristi (članak 5., stavak 1.). Ako spor ostane neriješen, Vijeće - na temelju prijedloga Komisije - može donijeti odluku da se odabere područje kao područje od značaja za Zajednicu (članak 5., stavak 2.). Takvu odluku Vijeće mora donijeti jednoglasno (članak 5., stavak 3.).

Kad se područje od značaja za Zajednicu usvoji, država članica ga mora odrediti kao posebno područje očuvanja što je prije moguće, a najkasnije u roku od šest godina (članak 4., stavak 4.). Međutim, takvo određivanje nema veliki značaj, budući da najvažnije pravne posljedice nastupaju već kad Komisija usvoji popis (članak 4., stavak 5.). Naime, od tog trenutka primjenjuju se odredbe članka 6., stavaka 2., 3. i 4. (v. dolje).

Čak štoviše, sukladno praksi Suda EU, iako se mjere zaštite propisane u članku 6., stavcima 2. do 4. zahtijevaju samo za područja koja se nalaze na popisu Komisije kao područja od značaja za Zajednicu, to ne znači da države članice nisu dužne štititi ta područja čim su ih, sukladno članku 4., stavku 1., predložile na nacionalnom popisu koji su proslijedile Komisiji. Ako ta područja nisu na odgovarajući način zaštićena od tog trenutka, postizanje ciljeva kojima se zahtijeva očuvanje prirodnih staništa i divlje faune i flore, kako je osobito navedeno u šestoj uvodnoj izjavi u preambuli Direktive i njezinom članku 3., stavku 1., moglo bi biti ugroženo. Takva situacija bi bila posebno ozbiljna ako bi se utjecalo na prioritetne prirodne stanišne tipove ili prioritetne vrste, za koje bi, zbog prijetnji kojima su

37 C-226/08 Stadt Papenburg [2010] ECR I-131, par. 27-33., cit. prema: Jans, Jan H.; Vedder, Hans H.B., European Environmental Law - After Lisbon, Europa Law Publishing, Groningen, 2012., str. 513. 
izložene, bilo prikladno rano provođenje mjera očuvanja, kao što je preporučeno u petoj uvodnoj izjavi u preambuli Direktive. ${ }^{38}$

Sa zemljama kandidatkinjama za članstvo u Europskoj uniji nisu bili dogovoreni nikakvi prijelazni periodi za uspostavljanje mreže Natura 2000 i od tih zemalja se zahtijevalo da, u skladu s Direktivom o pticama, proglase područja posebne zaštite te da, u skladu s Direktivom o staništima, predlože područja od značaja za Zajednicu, u trenutku njihova pristupanja EU. Dakle, države koje pristupaju Uniji moraju provoditi Direktivu o pticama i Direktivu o staništima od dana pristupanja Uniji. ${ }^{39}$

\section{b) Sprečavanje pogoršavanja, procjena planova i projekata i kompenzacijske mjere}

Države članice moraju poduzimati odgovarajuće korake kako bi se u posebnim područjima očuvanja izbjeglo pogoršanje prirodnih staništa i staništa vrsta, kao i uznemiravanje vrsta za koje su ta područja određena, u mjeri u kojoj bi takvo uznemiravanje moglo utjecati na ciljeve Direktive (članak 6., stavak 2.). Sukladno praksi Suda EU, moguće je da će biti nužno da države članice u svrhu provedbe ove odredbe moraju usvojiti i mjere namijenjene izbjegavanju vanjskih oštećenja i uznemiravanja uzrokovanih ljudskih djelovanjem i mjere za sprečavanje prirodnih promjena koje mogu prouzročiti pogoršanje statusa očuvanosti vrsta i staništa u posebnim područjima očuvanja. ${ }^{40}$ Međutim, ove preventivne obveze nisu apsolutne, budući da se u stavcima 3. i 4. članka 6. propisuje postupak koji se mora provesti u slučaju planova i projekata koji nisu izravno povezani s upravljanjem posebnog područja očuvanja niti potrebni za njegovo upravljanje, ali bi na njega mogli imati značajan utjecaj, bilo pojedinačno ili u kombinaciji s ostalim planovima ili projektima.

Kako bi se očuvala staništa od izgradnje ili drugih aktivnosti koje bi mogle promijeniti njihov ekološki integritet, članak 6., stavak 3. uređuje sui generis ocjenu prihvatljivosti utjecaja plana ili projekta koje bi mogao imati na posebna područja očuvanja, s obzirom na ciljeve očuvanja područja. ${ }^{41}$

Direktiva o staništima ne sadrži definiciju plana niti projekta. Jedino planovi i projekti koji su izravno povezani s upravljanjem posebnog područja očuvanja ili su potrebni za njegovo upravljanje ne podliježu ocjeni prihvatljivosti (primjerice, rušenje stabala koje je predviđeno u planu upravljanja određenim Natura 2000

38 C-117/03 Società Italiana Dragaggi SpA and Others v Ministero delle Infrastrutture e dei Trasporti, Regione Autonoma del Friuli Venezia Giulia [2005] ECR I-167, par. 26-27.

39 European Commission, The Habitats Directive, URL=http://ec.europa.eu/environment/nature/ legislation/habitatsdirective/index_en.htm.

40 C-6/04 Commission of the European Communities v United Kingdom of Great Britain and Northern Ireland [2005] ECR I-9017, par. 34.

41 de Sadeleer, N., ,,The Appropriate Impact Assessment and Authorisation Requirements of Plans and Projects likely to have significant impacts on Natura 2000 sites“, u: Environmental Law Network International Review $1+2 / 13$, str. 8 . 
područjem).$^{42}$ Ostali planovi i projekti predmet su ocjene prihvatljivosti ako bi mogli imati značajan utjecaj na posebno područje očuvanja, bilo pojedinačno ili u kombinaciji s ostalim planovima ili projektima. U praksi to znači da se procjena provodi u dva stadija.

Prvi stadij uključuje prethodnu ocjenu u kojoj se utvrđuje bi li plan ili projekt mogao imati značajan utjecaj na posebno područje očuvanja, bilo pojedinačno ili u kombinaciji s ostalim planovima ili projektima. Ako je odgovor na ovo pitanje potvrdan, onda je potrebno provesti drugi stadij tj. punu ocjenu prihvatljivosti. Kako se utvrđuje mogućnost značajnog utjecaja? Prema praksi Suda EU, zahtjev za odgovarajućom procjenom utjecaja plana ili projekta uvjetovan je time bi li mogao imati značajan utjecaj na područje. Dakle, za pokretanje mehanizma zaštite koji, predviđen u članku 6., stavku 3. Direktive o staništima, nije pretpostavka da plan ili projekt mora definitivno imati značajan utjecaj na područje, već on slijedi iz puke mogućnosti da se takav utjecaj može pridati planu ili projektu. ${ }^{43}$ Sukladno načelu predostrožnosti, nacionalna tijela moraju biti sigurna da neće biti negativnog utjecaja. ${ }^{44}$ Sud EU je zaključio da ,u svjetlu, osobito, načela predostrožnosti ... takav rizik postoji ako se ne može isključiti na osnovi objektivnih informacija“" odnosno da se u slučaju sumnje oko postojanja značajnog utjecaja mora provesti (puna) ocjena prihvatljivosti plana ili projekta. ${ }^{45}$

Nadalje, važno je istaknuti i da odgovor na pitanje postojanja značajnog utjecaja ne ovisi o tome je li neki projekt veliki ili mali. Prema stajalištu Suda EU, čak i projekt male veličine može imati značajan utjecaj na okoliš ako se nalazi na području gdje su okolišni faktori, poput faune i flore, tla, vode, klime ili kulturne baštine, osjetljivi na najmanje promjene ${ }^{46}$ Pored toga, značajnost utjecaja treba se sagledati i u svjetlu ciljeva očuvanja posebnog područja. Sud EU je utvrdio da se za bilo koju aktivnost koja bi mogla narušiti ciljeve očuvanja područja mora smatrati da može imati značajan utjecaj na njega ${ }^{47}$

Ako se utvrdi da bi plan ili projekt mogao imati značajan utjecaj na posebno područje očuvanja, bilo pojedinačno ili u kombinaciji s ostalim planovima ili projektima, slijedi drugi stadij postupka koji uključuje ocjenu prihvatljivosti utjecaja koje bi plan ili projekt mogao imati na to područje, s obzirom na ciljeve očuvanja područja. U pogledu pitanja kakva bi to trebala biti procjena da bi ona bila odgovarajuća u smislu članka 6., stavka 3., Sud EU je utvrdio sljedeće. Odredba članka 6., stavka 3. ne određuje neku posebnu metodu za provedbu takve procjene. Ipak, prema tekstu te odredbe, prije nego što se plan ili projekt odobri

42 Ibid., str. 9.

43 C-127/02 Landelijke Vereniging tot Behoud van de Waddenzee and Nederlandse Vereniging tot Bescherming van Vogels v Staatssecretaris van Landbouw, Natuurbeheer en Visserij „Waddenzee“" [2004] ECR I-7405, par. 41.

44 Jans, Jan H.; Vedder, Hans H.B., European..., op. cit., str. 517.

45 C-127/02, ,Waddenzee“, par. 44.

46 C-392/96 Commission of the European Communities v Ireland [1999] ECR I-5901, par. 66.

47 C-127/02 „Waddenzee“, par. 48. 
mora se provesti odgovarajuća procjena posljedica plana ili projekta na područje o kojem se radi i uzeti u obzir kumulativni učinci koji proizlaze iz kombinacije tog plana ili projekta s drugima planovima ili projektima u pogledu ciljeva očuvanja područja. Takva procjena stoga podrazumijeva da svi aspekti plana ili projekta - koji mogu bilo pojedinačno ili u kombinaciji s drugim planovima ili projektima utjecati na te ciljeve - moraju biti identificirani u svjetlu najboljih znanstvenih spoznaja u području. Ti se ciljevi mogu, kao što je to jasno iz članka 3. i 4. Direktive o staništima, a posebno njezinog članka 4., stavka 4., utvrditi na temelju, između ostalog, značaja područja za održavanje ili povrat u povoljno stanje očuvanosti prirodnog staništa tipa iz Priloga I. ili vrsta iz Priloga II. Direktive i za koherentnost Nature 2000 te prijetnji od pogoršanja ili uništenja kojima su ta područja izložena. ${ }^{48}$

Dakle, Sud EU je naglasio da se procjena mora provesti „u svjetlu najboljih znanstvenih spoznaja u području“. ${ }^{49}$ „Procjena na temelju članka 6. stavka 3. Direktive o staništima ne može se smatrati odgovarajućom ako sadrži praznine i nema potpune, precizne i konačne rezultate i zaključke kojima se može ukloniti sva razumna znanstvena sumnja u vezi utjecaja predloženih radova na posebno područje zaštite. “50 To znači da se procjena ne može smatrati odgovarajućom ako nedostaju pouzdani i ažurni podaci, a stručnjaci koji provode tu procjenu moraju imati visok stupanj kompetencije u odnosu na pitanja očuvanja prirode..$^{51}$

U drugoj rečenici stavka 3. članka 6. propisano je da u svjetlu zaključaka procjene utjecaja na područje i sukladno odredbama članka 6., stavka 4. (v. infra u ovom poglavlju), nadležna tijela državne vlasti smiju odobriti plan ili projekt tek nakon što se uvjere da on neće negativno utjecati na cjelovitost (integritet) dotičnog područja te, ako je to potrebno, nakon dobivanja mišljenja od šire javnosti.

U pogledu pitanja pod kojim se uvjetima određena aktivnost može odobriti, Sud EU je pružio sljedeće tumačenje članka 6., stavka 3. Direktive. Na nadležnim je državnim tijelima da, u svjetlu zaključaka procjene posljedica plana ili projekta za područje u pitanju, plan ili projekt odobre tek nakon što su sigurni da neće negativno utjecati na integritet tog područja. Stoga je jasno da se plan ili projekt može odobriti samo pod uvjetom da su nadležna državna tijela uvjerena kako on neće negativno utjecati na cjelovitost područja u pitanju. Dakle, ako postoji sumnja u pogledu nepostojanja štetnih utjecaja na cjelovitost područja povezanih s planom ili projektom koji se razmatra, nadležno tijelo mora odbiti odobrenje. Kriterij za odobravanje propisan u drugoj rečenici članka 6., stavka 3. Direktive o staništima integrira načelo predostrožnosti i omogućuje učinkovito sprečavanje negativnih učinaka na cjelovitost zaštićenih područja koji bi bili rezultat planova ili projekata koji se razmatraju. Blaži kriterij za odobravanje od toga ne bi mogao učinkovito osigurati ispunjenje cilja zaštite područja koji je određen prema toj

48 Ibid., par. 54.

49 Ibid.

50 C-404/09 European Commission v Kingdom of Spain [2011] ECR I-11853, par. 100.

51 de Sadeleer, N., The Appropriate..., op. cit., str. 13. 
odredbi. ${ }^{52}$ U pravnoj literaturi ovo tumačenje Suda EU naziva se: „in dubio pro natura".$^{53}$ Ako postoji ikakva sumnja u pogledu nepostojanja negativnih utjecaja, nadležno tijelo ne smije izdati odobrenje. ${ }^{54}$

Zaštita koju pruža Direktiva o staništima ipak nije apsolutna, što znači da se plan ili projekt mogu odobriti čak i ako su zaključci procjene da će imati negativan utjecaj na cjelovitost zaštićenog područja. Članak 6., stavak 4. propisuje da ako se, unatoč negativnoj procjeni utjecaja na područje i u nedostatku drugih pogodnih mogućnosti, plan ili projekt ipak moraju provesti zbog imperativnih razloga prevladavajućeg javnog interesa, uključujući interese socijalne ili gospodarske prirode, država članica poduzima sve kompenzacijske mjere kako bi osigurala zaštitu koherentnosti mreže Natura 2000. Država članica mora Komisiju izvijestiti o usvojenim kompenzacijskim mjerama. Kompenzacija se može sastojati od:

- obnavljanje staništa kako bi se osiguralo održavanje vrijednosti očuvanja i usklađenost s ciljevima očuvanja područja ili poboljšanje preostalog staništa razmjerno gubitku do kojeg će doći zbog provedbe plana ili projekta u području Natura 2000;

- ponovno stvaranje staništa na novom ili proširenom području, koje će se uvrstiti u Naturu 2000;

- predlaganje novog područja temeljem Direktive o staništima i Direktive o pticama. ${ }^{55}$

Međutim, kad se u određenom području nalazi prioritetni prirodni stanišni tip i/ili prioritetna vrsta, mogu se razmatrati samo ona pitanja koja se odnose na:

(1) zdravlje ljudi ili javnu sigurnost,

(2) korisne posljedice od primarnog značaja za okoliš ili

(3) imperativne razloge prevladavajućeg javnog interesa, o čemu je potrebno pribaviti prethodno mišljenje Komisije.

\section{NATURA 2000 U REPUBLICI HRVATSKOJ}

Prijedlog ekološke mreže Natura 2000 u Hrvatskoj izradio je Državni zavod za zaštitu prirode (dalje i: Zavod) kao središnja državna institucija za stručne poslove zaštite prirode ${ }^{56}$ Proces izrade prijedloga ekološke mreže Natura 2000 u Hrvatskoj

52 C-127/02, par. 58 .

53 Schoukens, H., „The Ruling of the Court of Justice in Sweetman: How to avoid a death by a thousand cuts?" U: Environmental Law Network International Review 1/14, str. 3.

54 de Sadeleer, N., The Appropriate..., op. cit., str. 16-17.

55 European Commission, Guidance document on Article 6(4) of the 'Habitats Directive' 92/43/ EEC, URL=http://ec.europa.eu/environment/nature/natura2000/management/docs/art6/guidance_art6_4 en.pdf, str. 14 .

56 Bitno je napomenuti da je Vladinom Uredbom (NN br. 72/15) osnovana Hrvatska agencija za okoliš i prirodu koja je preuzela sve funkcije Agencije za zaštitu okoliša i Državnog zavoda za zaštitu prirode. Danom upisa nove Agencije u sudski registar 17. rujna 2015., brisale su se po službenoj dužnosti iz sudskog registra Agencija za zaštitu okoliša i Državni zavod za zaštitu prirode (v. čl. 20., st. 1. Uredbe o osnivanju Hrvatske agencije za okoliš i prirodu). 
započeo je još 2001. godine kroz projekt Smaragdna mreža (Emerald Network) financiran od Vijeća Europe, a temeljem ugovora sklopljenog s Europskom agencijom za okolišs. ${ }^{57}$ Smaragdna mreža je ekološka mreža sastavljena od područja od posebne važnosti za zaštitu prirode (Areas of Special Conservation Interest $A S C I$ ), a dužne su je uspostaviti stranke Konvencije o zaštiti europskih divljih vrsta i prirodnih staništa (Bernska konvencija). ${ }^{58}$ Ona obuhvaća područja od ekološke važnosti za ugrožene vrste i stanišne tipove koji su zaštićeni temeljem Bernske konvencije, a za države kandidatkinje za članstvo u EU izrada Smaragdne mreže predstavlja pripremu za europsku mrežu Natura $2000 .{ }^{59}$ Od 2002. do 2005. godine Zavod je provodio projekt LIFE III „Uspostava Nacionalne ekološke mreže kao dijela Sveeuropske ekološke mreže i mreže Natura 2000 (CRO NEN)“ u okviru kojeg je izrađen nacrt karte nacionalne ekološke mreže kao osnove za Naturu $2000 .{ }^{60} \mathrm{Od} 2005$. do 2006. godine provedena je revizija nacionalne ekološke mreže temeljem prikupljenih podataka te je 2007. godine donesena Uredba o njezinom proglašavanju (NN br. 109/07). Ta je Uredba donesena na temelju tada važećeg Zakona o zaštiti prirode (NN br. 70/05) koji je predviđao paralelno postojanje nacionalne ekološke mreže i ekološke mreže Natura 2000. ${ }^{61}$ Odredbom čl. 203. Zakona o zaštiti prirode iz 2005. bilo je propisano da će se ekološki značajna područja koja će biti sastavnice europske ekološke mreže Natura 2000 utvrditi do dana pristupanja Hrvatske Europskoj uniji.

Zavod je 2008. godine priredio prvi prijedlog mreže Natura 2000 te je 2008. i 2009. godine kroz projekt PHARE 2005 „Institucionalno jačanje i provedba ekološke mreže Natura 2000 u Hrvatskoj“ proveo konzultacijski proces sa zainteresiranim dionicima. ${ }^{62}$ Također je donesen i Pravilnik o ocjeni prihvatljivosti plana, programa i zahvata za ekološku mrežu (NN br. 118/09), kojim je uspostavljen jedan od osnovnih mehanizama zaštite ekološke mreže i budućih područja Nature 2000 u Hrvatskoj.

Od 2010. do 2012. provodio se projekt IPA 2007 „Identifikacija i uspostavljanje morskog dijela mreže Natura 2000 u Hrvatskoj" s ciljem da se doprinese završetku izrade prijedloga morskih Natura 2000 područja u Hrvatskoj. ${ }^{63}$ Kao nastavak konzultacijskog procesa započetog u okviru PHARE projekta, u ožujku 2010.

57 Proces izrade prijedloga mreže Natura 2000 u Hrvatskoj opisan je u: Državni zavod za zaštitu prirode, Prijedlog ekološke mreže Natura 2000 - stručna podloga, Zagreb, studeni 2012., str. 29-35. V. i: Grgić, M., Varga, M., „Uspostava ekološke mreže Natura 2000 i uloga INSPIRE direktive“, Ekscentar, br. 16, 2013., str. 54-57.

58 NN-MU br. 6/00.

59 Državni zavod za zaštitu prirode, Prijedlog ekološke mreže Natura 2000 - stručna podloga, op. cit., str. 29.

60 Ibid., str. 30.

${ }_{61}$ V. Obrazloženje Prijedloga Uredbe o ekološkoj mreži, 117. sjednica Vlade Republike Hrvatske, 26. 9. 2013., točka 9. Dnevnog reda, https://vlada.gov.hr/UserDocsImages//Sjednice/Arhiva//117.\%20 -\%209.pdf.

62 Državni zavod za zaštitu prirode, Prijedlog ekološke mreže Natura 2000 - stručna podloga, op. cit., str. 30 .

63 V. Ibid., str. 32. 
osnovana je Radna skupina za definiranje šumskih područja unutar ekološke mreže Natura 2000 u Hrvatskoj u okviru koje je usuglašen Prijedlog područja Natura 2000 za koje su ciljni šumski stanišni tipovi. ${ }^{64}$

Za lakše snalaženje u terminologiji koja se koristi u direktivama, presudama Suda EU, mišljenjima nezavisnih odvjetnika, dokumentima Europske komisije i općenito u literaturi vezanoj za Naturu 2000, u tablici 2. prikazani su osnovni pojmovi te njihovi prijevodi na hrvatski jezik. Naime, činjenica da do nedavno nije postojao službeni prijevod pravne stečevine Europske unije na hrvatskom jeziku objavljen u službenom listu Europske unije dovela je do mnoštva različitih prijevoda istih termina. ${ }^{65}$ Dodatna okolnost koja se treba uzeti u obzir jest $\mathrm{i}$ Nacrt prijedloga Zakona o izmjenama i dopunama Zakona o zaštiti prirode, ${ }^{66}$ koji uvodi nove termine vezane za proces uspostavljanja ekološke mreže Natura 2000 u Hrvatskoj. Naime, Europska komisija uputila je Republici Hrvatskoj u ožujku 2015. godine EU Pilot broj 7371/15/ENVI koji ukazuje na nepotpuni i/ili netočan prijenos određenih odredbi Direktive o staništima te EU Pilot 7372/15/ ENVI u vezi s nepotpunim prijenosom odredbi Direktive o pticama. Stoga se predloženim izmjenama i dopunama Zakona o zaštiti prirode nastoji postići dodatno usklađivanje s odredbama navedenih direktiva.

Tablica 2.: Usporedni prikaz osnovnih termina na engleskom i hrvatskom jeziku

\begin{tabular}{|l|l|l|l|}
\hline $\begin{array}{c}\text { Birds Directive i } \\
\text { Habitats Directive } \\
\text { (engl. verzija) }\end{array}$ & $\begin{array}{c}\text { Direktiva o pticama i } \\
\text { Direktiva o staništima } \\
\text { (hrv. verzija) }\end{array}$ & $\begin{array}{c}\text { Uredba o } \\
\text { Ukološkoj mreži }\end{array}$ & $\begin{array}{c}\text { Nacrt } \\
\text { prijedloga } \\
\text { Zakona o } \\
\text { izmjenama } \\
\text { i dopunama } \\
\text { Zakona o } \\
\text { zaštiti prirode }\end{array}$ \\
\hline $\begin{array}{l}\text { SPA - Special } \\
\text { protection area }\end{array}$ & $\begin{array}{l}\text { Dva termina se koriste: } \\
\text { 1) Posebna zaštićena } \\
\text { područja (v. članak 4. } \\
\text { Direktive o pticama) } \\
\text { 2) Područja posebne } \\
\text { zaštite (v. članak 3. } \\
\text { stavak 1. Direktive o } \\
\text { staništima) }\end{array}$ & $\begin{array}{l}\text { POP - Područja } \\
\text { očuvanja } \\
\text { značajna za ptice }\end{array}$ & $\begin{array}{l}\text { Područja } \\
\text { očuvanja } \\
\text { značajna za } \\
\text { ptice }\end{array}$ \\
\hline
\end{tabular}

64 Ibid., str. 31.

65 Tako se, primjerice, u pojmovniku Državnog zavoda za zaštitu prirode (objavljenom na internetskoj stranici URL=http://www.dzzp.hr/pojmovnik/) special protection area (SPA) prevodi kao područja posebne zaštite, a special areas of conservation (SAC) kao posebna područja zaštite.

${ }_{66}$ Nacrt prijedloga objavljen je na portalu e-Savjetovanja: https://savjetovanja.gov.hr/. 


\begin{tabular}{|c|c|c|c|}
\hline $\begin{array}{l}\text { pSCI - proposed } \\
\text { Sites of } \\
\text { Community } \\
\text { importance }\end{array}$ & $\begin{array}{l}\text { predložena Područja od } \\
\text { značaja za Zajednicu }\end{array}$ & $\begin{array}{l}\text { predložena } \\
\text { Područja } \\
\text { očuvanja } \\
\text { značajna za } \\
\text { vrste i stanišne } \\
\text { tipove (nema } \\
\text { skraćenice) }\end{array}$ & $\begin{array}{l}\text { vPOVS - } \\
\text { vjerojatno } \\
\text { područje } \\
\text { očuvanja } \\
\text { značajno za } \\
\text { vrste i stanišne } \\
\text { tipove }\end{array}$ \\
\hline $\begin{array}{l}\text { SCI - Sites of } \\
\text { Community } \\
\text { importance }\end{array}$ & $\begin{array}{l}\text { Područja od značaja za } \\
\text { Zajednicu }\end{array}$ & $\begin{array}{l}\text { Područja } \\
\text { značajna za } \\
\text { Europsku } \\
\text { uniju (nema } \\
\text { skraćenice) }\end{array}$ & $\begin{array}{l}\text { Izravno ne } \\
\text { sadrži takav } \\
\text { pojam već } \\
\text { propisuje } \\
\text { da vPOVS } \\
\text { područja } \\
\text { podliježu } \\
\text { odobrenju } \\
\text { od strane } \\
\text { Europske } \\
\text { komisije i } \\
\text { postaju POVS } \\
\text { područja } \\
\text { danom objave } \\
\text { u Službenom } \\
\text { listu EU (v. } \\
\text { prijedlog } \\
\text { izmijenjenog } \\
\text { čl. 54. st. } 3 \text {. } \\
\text { i 4.) }\end{array}$ \\
\hline $\begin{array}{l}\mathrm{SAC}-\text { Special } \\
\text { areas of } \\
\text { conservation }\end{array}$ & $\begin{array}{l}\text { Posebna područja } \\
\text { očuvanja }\end{array}$ & $\begin{array}{l}\text { POVS - Područja } \\
\text { očuvanja } \\
\text { značajna za vrste } \\
\text { i stanišne tipove }\end{array}$ & $\begin{array}{l}\text { PPOVS - } \\
\text { Posebna } \\
\text { područja } \\
\text { očuvanja } \\
\text { značajna za } \\
\text { vrste i stanišne } \\
\text { tipove }\end{array}$ \\
\hline
\end{tabular}

** Direktive su objavljene u posebnom izdanju Službenog lista EU na hrvatskom jeziku. U tom posebnom izdanju objavljuje se sekundarno zakonodavstvo koje stupa na snagu na dan pristupanja određene države članice. Objavljeni akti u posebnim izdanjima raspodijeljeni su po svescima redoslijedom njihova objavljivanja i u 20 poglavlja koja su u skladu s poglavljima registra zakonodavstva Europske unije. V. URL=http://eur-lex.europa.eu/eu-enlargement/hr/special.html?locale=hr. 
U tablici 3. prikazani su podaci o površinama područja mreže Natura 2000 kako je bilo predloženo u Prijedlogu Uredbe o ekološkoj mreži. ${ }^{67}$ Sukladno novom Zakonu o zaštiti prirode (NN br. 80/13), područja Nature 2000 u Hrvatskoj nazivaju se ekološka mreža. Kada se sagledava udio ekološke mreže u ukupnoj površini Hrvatske, postoje razlike u udjelima u kontinentalnoj Hrvatskoj i krškom području Hrvatske. Kontinentalni dio Hrvatske po prirodi je sličan zemljama srednje Europe te je tako i svojim postotkom blizak tim zemljama ${ }^{68}$ Krško područje Hrvatske je svojom biološkom raznolikošću izuzetno bogato te je jedno od najvažnijih područja očuvane prirode u Europi, pa svojim postotkom mreža Natura 2000 odskače od europskog prosjeka. ${ }^{69}$

Tablica 3.: Površina područja mreže natura $2000^{70}$

\begin{tabular}{|c|c|c|c|c|c|c|c|}
\hline & $\begin{array}{c}\text { Površina } \\
\text { kopna } \\
\text { RH (km2) }\end{array}$ & $\begin{array}{c}\text { \% kopna } \\
\text { RH }\end{array}$ & $\begin{array}{c}\text { Površina } \\
\text { Teritorijalno } \\
\text { more RH } \\
\text { (km2) }\end{array}$ & $\begin{array}{c}\text { \% } \\
\text { teritorijalno } \\
\text { more RH }\end{array}$ & $\begin{array}{c}\text { Ukupna } \\
\text { površina } \\
\text { RH } \\
\text { (km2) }\end{array}$ & $\begin{array}{c}\text { \% } \\
\text { ukupne } \\
\text { površine } \\
\text { RH }\end{array}$ & $\begin{array}{c}\text { Broj } \\
\text { područja } \\
\text { Natura } \\
\mathbf{2 0 0 0}\end{array}$ \\
\hline $\begin{array}{c}\text { Područja } \\
\text { očuvanja } \\
\text { značajna } \\
\text { za vrste i } \\
\text { stanišne } \\
\text { tipove } \\
\text { (pSCI) }\end{array}$ & 16059,57 & 28,38 & 4903,12 & 15,44 & 20962,69 & 23,73 & 742 \\
\hline $\begin{array}{c}\text { Područja } \\
\text { očuvanja } \\
\text { značajna } \\
\text { za ptice } \\
\text { (SPA) }\end{array}$ & 17107,55 & 30,23 & 1040,13 & 3,28 & 18147,68 & 20,54 & 38 \\
\hline $\begin{array}{c}\text { Natura } \\
\text { 2000 } \\
\text { (ekološka } \\
\text { mreža) }\end{array}$ & 20754,97 & 36,67 & 5204,63 & 16,39 & 25959,6 & 29,38 & 780 \\
\hline
\end{tabular}

Europska je unija podijeljena u devet kopnenih biogeografskih regija: alpinska (alpska), ${ }^{71}$ kontinentalna, mediteranska, panonska, stepska, borealna, atlantska,

67 Prijedlog Uredbe o ekološkoj mreži, 117. sjednica Vlade Republike Hrvatske, op. cit.

68 Državni zavod za zaštitu prirode, Prijedlog ekološke mreže Natura 2000 - stručna podloga, op. cit., str. 35 .

69 Ibid.

70 Izvor: Prijedlog Uredbe o ekološkoj mreži, 117. sjednica Vlade Republike Hrvatske, op. cit.

71 Na različitim mjestima koristi se ponekad naziv alpska, a ponekad alpinska regija. Usp. primjerice Pojmovnik Državnog zavoda za zaštitu prirode (URL=http://www.dzzp.hr/pojmovnik/) te Standardni 
crnomorska i makaronezijska. ${ }^{72}$ Podjela na regije omogućava ocjenu dostatnosti ekološke mreže svake zemlje članice, kao i praćenje trendova očuvanosti vrsta i staništa u sličnim uvjetima diljem Europe. ${ }^{73}$ Hrvatska obuhvaća alpinsku, kontinentalnu i mediteransku regiju. Ekološka mreža Republike Hrvatske proglašena je Uredbom o ekološkoj mreži (NN br. 124/13). Tom su se Uredbom u pravni poredak Republike Hrvatske prenijele Direktiva o staništima i Direktiva o pticama (v. članak 2. Uredbe).

U Zagrebu je 29. i 30. rujna 2014. održan biogeografski seminar za Hrvatsku, s ciljem procjene dostatnosti proglašene ekološke mreže za uvrštavanje u mrežu Natura 2000. ${ }^{74}$ Biogeografski seminari se održavaju za svaku biogeografsku regiju zasebno, a na njima se vodi znanstvena rasprava o prijedlogu područja Nature 2000 koji je predala nova država članica pri pristupanju u EU. ${ }^{75}$ Opća uprava za okoliš Europske komisije ( $D G$ Environment) predsjeda raspravi na seminarima, a Europski tematski centar za biološku raznolikost ${ }^{76}$ daje znanstvenu ocjenu prijedloga. Na temelju zaključaka biogeografskog seminara, došlo je do određenih dopuna prijedloga Područja očuvanja značajnih za vrste i stanišne tipove ${ }^{77}$ te je Vlada Republike Hrvatske u rujnu 2015. donijela Uredbu o izmjeni Uredbe o ekološkoj mreži (NN br. 105/15). U tablici 4. prikazani su pojedini koraci koji se trebaju poduzeti u tijeku procesa uspostavljanja Nature 2000.

obrazac Natura 2000 u Prilogu Provedbene Odluke Komisije od 11. srpnja 2011. o formatu podataka o područjima za područja Natura, OJ L 198, 30. 7. 2011., str. 39-70, posebno izdanje na hrvatskom jeziku: poglavlje 15, svezak 13, str. 216-247.

72 Natura 2000: Habitats Directive Sites according to Biogeographical Regions, URL=http:// ec.europa.eu/environment/nature/natura2000/sites_hab/biogeog_regions/index_en.htm.

73 Državni zavod za zaštitu prirode, Prijedlog ekološke mreže Natura 2000 - stručna podloga, op. cit., str. 3 .

74 Internetski portal zaštite prirode Ministarstva zaštite okoliša i prirode: „Održan biogeografski seminar za Hrvatsku“, URL=http://www.zastita-prirode.hr/Novosti-i-dogadanja/Odrzan-biogeografskiseminar-za-Hrvatsku.

75 V. Državni zavod za zaštitu prirode, Pojmovnik - URL=http://www.dzzp.hr/pojmovnik/.

76 European Topic Centre on Biological Diversity (ETC/BD), URL=http://bd.eionet.europa.eu/. Europski tematski centri su konzorciji institucija diljem zemalja članica Europskog gospodarskog prostora koji se bave određenom temom zaštite okoliša temeljem ugovora koji sklapaju s Europskom agencijom za okoliš.

77 V. Internetski portal zaštite prirode Ministarstva zaštite okoliša i prirode: „Održan biogeografski seminar za Hrvatsku“, op. cit. 
Dr. sc. Lana Ofak: Uspostavljanje i zaštita ekološke mreže Natura 2000 u Europskoj uniji i Hrvatskoj Zbornik radova Pravnog fakulteta u Splitu, god. 53, 2/2016., str. 623.-646.

Tablica 4.: Proces uspostavljanja ekološke mreže Natura 2000

\begin{tabular}{|c|c|c|}
\hline Razdoblje & $\begin{array}{l}\text { Aktivnosti i obveze prema Direktivi o } \\
\text { staništima i Direktivi o pticama }\end{array}$ & $\begin{array}{c}\text { Proces uspostavljanja } \\
\text { ekološke mreže u } \\
\text { Hrvatskoj }\end{array}$ \\
\hline $\begin{array}{c}\text { Prije } \\
\text { pristupanja } \\
\text { Europskoj } \\
\text { uniji }\end{array}$ & $\begin{array}{l}\text { Izmjene i dopune priloga Direktive o } \\
\text { staništima i Direktive o pticama tj. } \\
\text { usvajanje Direktive Vijeća 2013/17/ } \\
\text { EU od 13. svibnja 2013. o prilagodbi } \\
\text { određenih direktiva u području okoliša } \\
\text { zbog pristupanja Republike Hrvatske }\end{array}$ & $\begin{array}{l}\text { - Uredba o } \\
\text { proglašavanju ekološke } \\
\text { mreže (NN br. 109/07) } \\
\text { - uspostavljanje tzv. } \\
\text { nacionalne ekološke } \\
\text { mreže }\end{array}$ \\
\hline $\begin{array}{l}\text { Nakon } \\
\text { pristupanja } \\
\text { Europskoj } \\
\text { uniji }\end{array}$ & 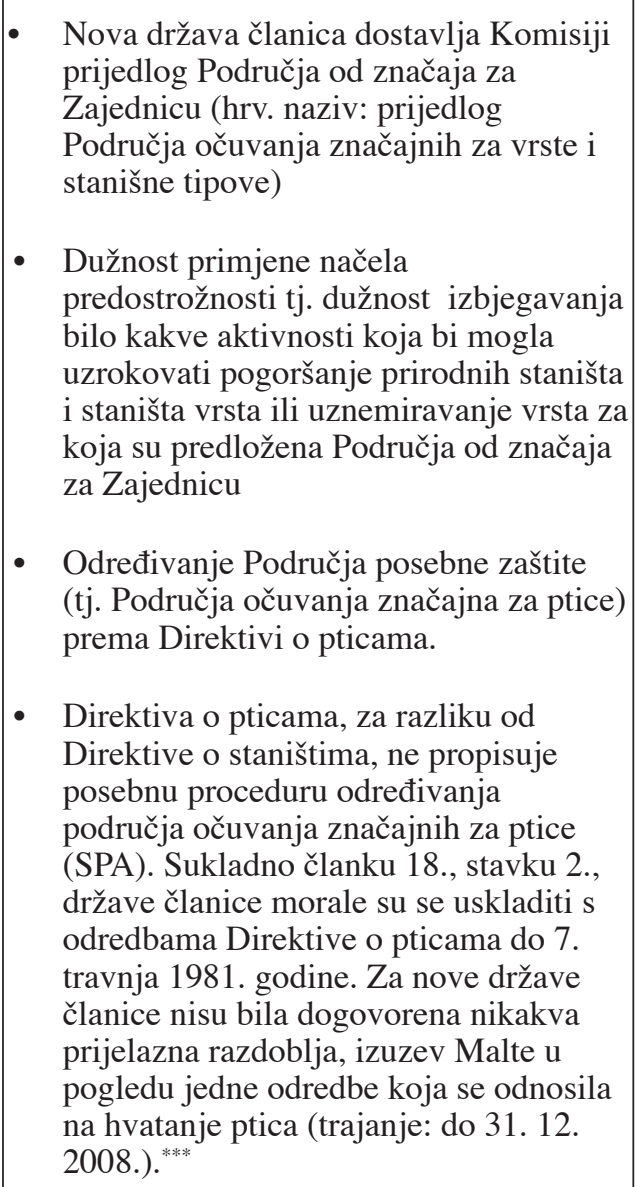 & $\begin{array}{l}\text { - Stupanje na snagu } \\
\text { Uredbe o ekološkoj } \\
\text { mreži (NN br. 124/13 i } \\
\text { 105/15). } \\
\text { Po stupanju na snagu } \\
\text { Uredbe o ekološkoj } \\
\text { mreži Ministarstvo } \\
\text { zaštite okoliša i prirode } \\
\text { dostavlja Europskoj } \\
\text { komisiji podatke i } \\
\text { kartografski prikaz } \\
\text { Područja očuvanja } \\
\text { značajna za vrste i } \\
\text { stanišne tipove radi } \\
\text { provedbe postupka } \\
\text { potvrđivanja koji } \\
\text { se provodi u vidu } \\
\text { biogeografskih } \\
\text { seminara te bilateralnih } \\
\text { konzultacija (v. čl. } 7 ., \\
\text { st. 1. Uredbe). } \\
\text { Stupanje na snagu } \\
\text { Pravilnika o ciljevima } \\
\text { očuvanja i osnovnim } \\
\text { mjerama za očuvanje } \\
\text { ptica u području } \\
\text { ekološke mreže (NN } \\
\text { br. 15/2014). }\end{array}$ \\
\hline
\end{tabular}




\begin{tabular}{|c|c|c|}
\hline $\begin{array}{l}\text { U roku od } \\
\text { tri godine } \\
\text { od dana } \\
\text { pristupanja } \\
\text { EU }\end{array}$ & $\begin{array}{l}\text { - Održavanje biogeografskih seminara i } \\
\text { bilateralnih konzultacija }\end{array}$ & $\begin{array}{l}\text { - } \text { Temeljem zaključka } \\
\text { Europske komisije } \\
\text { nakon biogeografskih } \\
\text { seminara i bilateralnih } \\
\text { konzultacija, Hrvatska } \\
\text { agencija za okoliš i } \\
\text { prirodu usklađuje popis } \\
\text { Područja očuvanja } \\
\text { značajnih za vrste } \\
\text { i stanišne tipove, a } \\
\text { Ministarstvo dostavlja } \\
\text { usklađeni popis } \\
\text { Europskoj komisiji (v. } \\
\text { čl. 7., st. 2. Uredbe o } \\
\text { ekološkoj mreži) }\end{array}$ \\
\hline $\begin{array}{l}\text { U roku od } \\
\text { šest godina } \\
\text { od dana } \\
\text { pristupanja } \\
\text { EU }\end{array}$ & $\begin{array}{l}\text { Komisija usvaja popis područja } \\
\text { odabranih kao područja od značaja za } \\
\text { Zajednicu (v. čl. 4., st. 3. Direktive o } \\
\text { staništima) }\end{array}$ & $\begin{array}{l}\text { - Nakon finalnog } \\
\text { zaključka Europske } \\
\text { komisije o dostatnosti } \\
\text { Područja očuvanja } \\
\text { značajnih za vrste i } \\
\text { stanišne tipove koje je } \\
\text { predložila Republika } \\
\text { Hrvatska i objave } \\
\text { popisa tih područja } \\
\text { u službenom glasilu } \\
\text { Europske unije, } \\
\text { ona dobivaju status } \\
\text { Područja značajnih } \\
\text { za Europsku uniju (v. } \\
\text { čl. 7., st. 3. Uredbe } \\
\text { o ekološkoj mreži). } \\
\text { Prema prijedlogu } \\
\text { izmjene čl. 54., st. } \\
\text { 4. vPOVS područja } \\
\text { postaju POVS } \\
\text { područja danom } \\
\text { objave u Službenom } \\
\text { listu Europske unije } \\
\text { (v. Nacrt prijedloga } \\
\text { Zakona o izmjenama } \\
\text { i dopunama Zakona o } \\
\text { zaštiti prirode). }\end{array}$ \\
\hline
\end{tabular}




\begin{tabular}{|c|c|c|}
\hline $\begin{array}{c}\text { U roku od } \\
\text { šest godina od } \\
\text { dana usvajanja } \\
\text { popisa } \\
\text { odabranih } \\
\text { kao područja } \\
\text { od značaja } \\
\text { za Zajednicu } \\
\text { područja }\end{array}$ & $\begin{array}{l}\text { - Kad se područje od značaja za Zajednicu } \\
\text { usvoji, dotična država članica ga } \\
\text { određuje kao posebno područje očuvanja } \\
\text { što je prije moguće, a najkasnije u roku } \\
\text { od šest godina (v. čl. 4., st. 4. Direktive o } \\
\text { staništima). } \\
\text { - Za posebna područja očuvanja, države } \\
\text { članice utvrđuju potrebne mjere za } \\
\text { očuvanje (v. čl. 6., st. 1. Direktive o } \\
\text { staništima). }\end{array}$ & $\begin{array}{l}\text { Prema Prijedlogu } \\
\text { zakona o izmjenama } \\
\text { i dopunama Zakona o } \\
\text { zaštiti prirode, ministar } \\
\text { nadležan za poslove } \\
\text { zaštite prirode donijet } \\
\text { će Pravilnik, najkasnije } \\
\text { do 23. siječnja 2021., } \\
\text { kojim će propisati } \\
\text { ciljeve očuvanja i } \\
\text { osnovne mjere za } \\
\text { očuvanje ciljnih vrsta, } \\
\text { izuzev ptica,**** te } \\
\text { stanišnih tipova u } \\
\text { području ekološke } \\
\text { mreže i način provedbe } \\
\text { mjera očuvanja (v. } \\
\text { prijedlog izmjene čl. } \\
\text { 55., st. 4.). Pravilnik } \\
\text { bi se trebao donijeti uz } \\
\text { suglasnost središnjeg } \\
\text { tijela državne uprave } \\
\text { nadležnog za poslove } \\
\text { poljoprivrede, } \\
\text { šumarstva, lovstva, } \\
\text { ribarstva i vodnoga } \\
\text { gospodarstva. } \\
\text { Danom stupanja na } \\
\text { snagu tog Pravilnika } \\
\text { POVS područja } \\
\text { utvrđena Uredbom } \\
\text { o ekološkoj mreži } \\
\text { postaju PPOVS } \\
\text { područja (v. prijedlog } \\
\text { izmjene čl. 54., st. 5.). }\end{array}$ \\
\hline
\end{tabular}

*** v. The Birds Directive, Frequently asked questions, URL=http://ec.europa.eu/environment/ nature/legislation/birdsdirective/index_en.htm.

**** Ptice su ovdje isključene budući da se na njih primjenjuje Pravilnik o ciljevima očuvanja i osnovnim mjerama za očuvanje ptica u području ekološke mreže (NN br. 15/2014). 


\section{ZAKLJUČAK}

Hrvatska ima svoj domaći sustav zaštite prirode čija je uspostava započela u prvoj polovici 20. stoljeća. Prvi nacionalni parkovi u Hrvatskoj (Plitvička jezera, Bijele stijene u Velikoj Kapeli, Štirovača i Paklenica) proglašeni su 1928., temeljem odredbe Financijskog zakona od 1928./29. Budući da je odredba članka Financijskog zakona o nacionalnim parkovima vrijedila samo do 1929. godine, i nije produljena, proglašeni parkovi pravno su postojali samo jednu godinu. ${ }^{78}$ Aktivnosti vezane za stavljanje prirodnih vrijednosti pod zaštitu države nastavile su se nakon donošenja Zakona o zaštiti spomenika kulture i prirodnih rijetkosti 1945. godine. Prema danas važećem Zakonu o zaštiti prirode, nacionalne kategorije zaštićenih područja jesu: strogi rezervat, nacionalni park, posebni rezervat, park prirode, regionalni park, spomenik prirode, značajni krajobraz, park-šuma i spomenik parkovne arhitekture (v. članak 111., stavak 1., točka 1.). Zaštićena područja danas obuhvaćaju 8,56 \% ukupne površine Republike Hrvatske, odnosno $12,23 \%$ kopnenog teritorija i $1,94 \%$ teritorijalnog mora. Najveći dio zaštićene površine su parkovi prirode $\left(4,56 \%\right.$ ukupnog državnog teritorija). ${ }^{79}$

U okviru procesa pridruživanja Europskoj uniji, Hrvatska se obvezala usklađivati postojeće zakone i buduće zakonodavstvo s pravnom stečevinom Europske unije. U području prava zaštite prirode to, između ostalog, podrazumijeva uspostavljanje ekološke mreže Natura 2000. Natura 2000 je zajednička osnova teritorijalne zaštite prirode u Europskoj uniji. Države članice i dalje imaju pravo zaštititi i druge dijelove teritorija prema vlastitim tradicijama i potrebama, kao i zadržati postojeći nacionalni sustav zaštićenih područja prirodnih vrijednosti. Stoga, Natura 2000 ne zamjenjuje nacionalne sustave zaštite prirode, već ih dopunjuje, a često se događa i prostorno preklapanje europskog sustava i nacionalnih sustava zaštićenih područja prirode.$^{80}$ Prema podacima Barometra Natura, ekološka mreža Natura 2000 proteže se na 18,14 \% teritorija Europske unije. ${ }^{81}$ Među državama članicama postoje velike razlike. Primjerice, država s najmanjim postotkom je Danska $(8,34 \%$ ), a s najvećim postotkom je Slovenija $(37,84 \%)$. Hrvatska zauzima drugo mjesto, nakon Slovenije. ${ }^{82}$

Mnogo država članica EU imalo je problema u pogledu primjene kriterija za određivanje područja posebne zaštite (SPA, hrv. POP) temeljem Direktive o pticama te posebnih područja očuvanja (SAC, hrv. POVS) temeljem Direktive o

78 Internetski portal zaštite prirode Ministarstva zaštite okoliša i prirode, URL=http://www.zastitaprirode.hr/Zasticena-priroda/Zastita-prirode-u-Republici-Hrvatskoj/Povijest-zastite-prirode-u-RepubliciHrvatskoj.

79 Izvor: Upisnik zaštićenih područja (stanje 9. rujna 2015.), URL=http://www.dzzp.hr/zasticenapodrucja/zasticena-podrucja-u-hrvatskoj/zasticena-podrucja-u-hrvatskoj-nacionalne-kategorije-1137. html.

80 Tomoszkova, V. et al., Implementation and Enforcement of EU Environmental Law in the Visegrad Countries, Palacky University, Olomouc, 2014., str. 48.

81 V. Natura 2000 Newsletter, no. 38, June 2015, str. 8, URL=http://ec.europa.eu/environment/nature/ info/pubs/docs/nat2000newsl/nat38_en.pdf.

82 Ibid., str. 8. i 9. 
staništima. Europska komisija je pokretala postupke protiv država članica pred Sudom Europske unije (tzv. infrakcijski postupci, engl. infringement procedure) kad god je smatrala da su ciljevi uspostavljanja koherentne mreže zaštićenih područja ugroženi time što određena područja na kojima se nalazi značajan broj ili površina zaštićenih vrsta ili staništa navedenih u prilozima direktiva nisu uključena u tu mrežu. ${ }^{83}$

Postupak uspostavljanja ekološke mreže dug je proces koji traje godinama. No to ne znači da zaštita područja, koja će tek postati područja od interesa za Europsku uniju kad ih usvoji Europska komisija, ne treba biti pružena odmah čim je u Hrvatskoj stupila na snagu Uredba o ekološkoj mreži. Naime, odredbe o očuvanju ekološke mreže moraju se odnositi i na područja koje država članica uvrsti na nacionalnu listu (pSCI, tj. predložena područja očuvanja značajna za vrste i stanišne tipove), koju dostavlja Europskoj komisiji na potvrđivanje. Ta obveza jasno je izražena u presudama Suda Europske unije, a navelo ju je i Ministarstvo zaštite okoliša i prirode u svom izvješću o provedenom javnom savjetovanju o Nacrtu prijedloga Zakona o izmjenama i dopunama Zakona o zaštiti prirode. ${ }^{84}$

U veljači 2014. Europska komisija odlučila je pokrenuti evaluaciju Direktive o pticama i Direktive o staništima i tako utvrditi jesu li djelotvorne u zaštiti prirode. ${ }^{85}$ Ta se aktivnost provodi u sklopu Programa REFIT kojim se želi osigurati prikladnost i učinkovitost propisa. ${ }^{86}$ Pitanja koja se istražuju jesu:

- učinkovitost (jesu li ispunjeni ciljevi?), - ekonomičnost (jesu li troškovi razumni?),

- usklađenost (nadopunjavaju li se druge aktivnosti ili postoje kontradikcije?),

- relevantnost (je li djelovanje EU još uvijek potrebno?) te

- dodana vrijednost EU (bi li se slične promjene postignule na nacionalnoj/ regionalnoj razini, ili je djelovanje EU jasno pružilo dodatnu vrijednost?). ${ }^{87} \mathrm{Na}$ inicijativu Njemačke, 26. listopada 2015., 9 ministara zaštite okoliša (Hrvatska, Njemačka, Francuska, Italija, Luksemburg, Poljska, Rumunjska, Slovenija,

83 Detaljno o tome v. Schoukens, H.; Woldendorp, H. E., „Site selection and designation under Habitats and Birds Directives: a Sisyphean task?“ u: Born, C.-H.; Cliquet, A.; Schoukens, H.; Misonne, D.; Van Hoorick, G.; (eds.), The Habitats Directive in its EU Environmental Context - European Nature's Best Hope, str. 31-55.

84 „Definicija ekološke mreže Natura 2000 uzima u obzir i presude Europskog suda pravde iz kojih je evidentno da se odredbe o očuvanju moraju odnositi i na vPOVS područja (pSCI područja), dakle na područja koja država članica uvrsti na nacionalnu listu (u Hrvatskoj se to ostvaruje uvrštavanjem na popis Uredbe o ekološkoj mreži), a koja još nije potvrdila Europska komisija u postupku Biogeografskog seminara." Cit. prema Izvješću o provedenom savjetovanju - Javno savjetovanje o Nacrtu prijedloga Zakona o izmjenama i dopunama Zakona o zaštiti prirode, dostupno na: https://esavjetovanja.gov.hr/ ECon/Dashboard.

85 Fitness Check of EU Nature Legislation (Birds and Habitats Directives), URL=http://ec.europa.eu/ environment/nature/legislation/fitness_check/index_en.htm. hr.htm.

86 Europska komisija, Program REFIT, URL=http://ec.europa.eu/smart-regulation/refit/index

87 Fitness Check of EU Nature Legislation (Birds and Habitats Directives), URL=http://ec.europa.eu/ environment/nature/legislation/fitness_check/index_en.htm. 
Španjolska) potpisalo je u Luxembourgu pismo povjereniku Velli u kojemu se zalažu za zadržavanje dviju Natura 2000 direktiva u svom sadašnjem obliku te vjeruju da izmjene i dopune direktiva ne bi bile svrhovite. ${ }^{88}$ Izvješće Komisije o rezultatima provedbe evaluacije očekuju se u drugom kvartalu 2016. godine. Prema novom izvješću o stanju prirode State of Nature in the $E U{ }^{89}$ samo četvrtina vrsta zaštićenih temeljem Direktive o staništima (točnije $23 \%$ ) ima povoljan status očuvanja. Više od polovice $(60 \%)$ i dalje je u nepovoljnom stanju od čega se $42 \%$ smatra da je u neadekvatnom stanju, a $18 \%$ u lošem. Stoga na kraju ovog rada možemo samo izraziti nadu da će rezultati evaluacije Direktive o pticama i Direktive o staništima pokazati da je potrebno usredotočiti se na jačanje i unapređenje njihove provedbe, a ne na njihovu izmjenu.

\section{THE ESTABLISHMENT AND THE PROTECTION OF THE NATURA 2000 NETWORK IN THE EUROPEAN UNION AND CROATIA}

This paper clarifies the provisions of EU legislation concerning the nature protection which have established the ecological network Natura 2000 (Directive 2009/147/EC on the conservation of wild birds and Directive 92/43/EEC on the conservation of natural habitats and of wild fauna and flora). For this purpose, the paper presents the judgments of the Court of Justice of the European Union concerning the interpretation of the provisions of the respective directives. The goal is to provide with an answer to the question regarding the process of establishment of the ecological network Natura 2000 and the level of nature protection which Member States must provide when they are approving projects that may have adverse impacts on the protected areas. The paper then analyses the process of establishing the Natura 2000 network in Croatia. Since the process of establishing the ecological network can last for years, special attention is paid to the question of the moment from which the Member States are obliged to protect the areas that will become Sites of Community Importance when they are adopted by the European Commission. The paper also points to the problem of noncompliance of certain basic terms in the translation of the EU legislation into Croatian. The paper, thus, clarifies certain differences in terminology that exist in the current Croatian legislation and its proposed amendments.

Keywords: nature protection, ecological network Natura 2000, Directive on the conservation of natural habitats and of wild fauna and flora, Directive on the conservation of wild birds

${ }_{88}$ Ministarstvo zaštite okoliša i prirode, Priopćenje za javnost 26. 10. 2015., URL=http://mzoip.hr/hr/ ministarstvo/vijesti/devet-ministara-okolisa-eu-a-potpisalo-pismo-u-kojemu-se-zalazu-za-zadrzavanjedirektiva-u-sadasnjem-obliku.html. U pismu se, između ostalog, navodi: „Europske direktive za očuvanje prirode dokazale su svoju vrijednost i postale su ključnim dijelom očuvanja biološke raznolikosti u Europi. Bez njih će biti nemoguće postići ciljeve EU strategije biološke raznolikosti za razdoblje do 2020. godine. Vidljivi su prvi znakovi uspjeha. Sada postoji pravna sigurnost koja je rezultat vrlo uznapredovale provedbe. Oni na koje utječe naučili su se nositi s odredbama direktiva. Svaka izmjena i dopuna zahtijevala bi dodjelu osoblja i financijskih sredstava za razdoblje u trajanju mnogo godina što bi dovelo do toga da ovi resursi ne bi više bili dostupni za puno važniji proces provedbe direktiva za očuvanje prirode. To bi rezultiralo novom pravnom nesigurnosti.“

89 European Environment Agency, State of Nature in the EU, Results from reporting under the nature directives 2007-2012, Luxembourg: Publications Office of the European Union, 2015., URL=http://www. eea.europa.eu/publications/state-of-nature-in-the-eu. 